\title{
THE ACTIVE PERCEPTION OF ART MUSIC AT THE LOWER LEVEL OF SECONDARY SCHOOL EDUCATION
}

\author{
Marianna Kolostova - Jarmila Papova
}

\author{
DOI: 10.18355/PG.2015.4.2.248-258
}

\begin{abstract}
The paper is focused on the issue of active perception of art music. It deals with concerts for children as one of the forms of active perception in the process of music education at the lower level of secondary education. It presents the results of pedagogic research conducted through an experiment aimed at the area of influence of the active perception of art music for increasing pupils' relationship to music.
\end{abstract}

\section{Key words}

active perception, art music, concerts for children, pedagogic research

\section{Introduction}

As today the process of music education is constantly being exposed to the increasingly strong influence of rapidly changing musical communication the role of the observational, analytical, investigative and experimental skills of teachers working in this education field is increasing. Developing the aforementioned skills of teachers today is all the more important as traditional music education poorly competes with the functional role of music on a perceptive, sensitive and a sufficiently unimmunized young generation. For music education it is an important signal that music teachers should not be closed to the world in some kind of professional isolationism but should strive to develop their own observational activities and to design new creative tasks in order to provide the impetus to overcome current obstacles in the music education environment. In Slovak schools the traditional teaching model with an emphasis on verbal explanations is declining and a system which develops the personal abilities of pupils according to the program triplet of experience, skill, knowledge is being preferred. This change of priorities fully takes into account the natural function of music in human life and is becoming the basis for music education in schools according to the new curriculum.

\footnotetext{
Art (artifical) Music - a technical musicological term indicating that the music is serious, classical, artistic. It is connected to the understanding of the 'ars' in its historical meaning as something complex and beautiful. It is music which due to it aims and parameters belongs to a broader complex of artistic expressions, it developed in a more or less continual linear with European art as something relatively compact (in spite of passing through multiple styles, genres, schools and directions) and settled. Within a musical composition, the system focusing on musical and aesthetic criteria is dominate, so it is important its aesthetic autonomy (that its aim is above all to act aesthetically). The fact that something belongs to the category of art music does not on its own guarantee its musical value.

www.public.sk/web/kniznica/elpub/dokument/Kopcakova1/subor/2_cast.pdf, page 33 .
} 


\section{Active perception in theoretical reflection}

During the second half of the last century receptive music education was the most prevalent. Particularly significant was its expression in the methodology created by V. Fedor, who produced the first methodology 'playing,' (listening), through this work the theoretical requirements of V. Helfert were given in receptive music education specific and practical applications. A current handling of the new concepts in perceptual activities was provided in the eighties by a study in the Proceedings of the Slovak society for musical education entitled Pedagogical interpretations of a musical composition. The importance of musical perception in intentional education is demonstrated by the significant number of musical educationalists who have detailed their thinking in many published forms 1 . Without claiming that it is a complete list the following should be included: F. Sedlak, J. Herden, E. Jenckova, M. Kolar, M. Juzel, V. Drabek, L. Burlas, J. Hatrik, E. Michalova, E. Langsteinova, B. Felix, B. KalafutovaBalcarova, M. Schneiderova, D. Michalkova, J. Hudakova.

Active perception2 is a way of listening to music which supposes the active participation of the child listener with enforcement through elements of creativity. It is based on the need to use an appropriate method of connecting the child perceiver to the musical composition and not only offer information and large amounts of facts but mediate their active connection to the music. According to Herden active perception has two characteristics: musical activity that is experiences gained through singing, playing an instrument, movement or dramatic activities and mental activity which is based on primary mental operations (Herden, 2010). Active perception includes being interested in creating musical compositions but it also covers a willingness to attend concerts, share about your experiences and emotions, encourage artists that their artistic work has meaning, motivate composers to create new works and more. Based on what has been outlined and in accordance with Herden the term active perception will be used in this article.

\section{Concerts for children}

Concerts for children and young people have over time undergone many conceptual changes. On the basis of long term research and collaboration with Austrian institutes Burgrova compiled a typology of concerts for children and young people: concerts with a typical form and a moderator

\footnotetext{
${ }^{1}$ Creative approaches to active perception is reflected in works by HERDEN, J. JENCKOVA, E. KOLAR, J. Hudba pro deti : UK 1992. HERDEN J. My pozor dame a poslouchame. Praha : Scientia 1994. My pozor dame a nejen poslouchame. Praha : Scientia 1997. DRABEK, V. Tvorivost a integrace v receptivni hudebni vychove. Praha : UK 1998. BURLAS, L. Hudba komunikativny dynamizmus. Bratislava : NOC 1998.

${ }^{2}$ In musical terminology in the Czech Republic and Slovakia there is considerable disunity: Certain specialists prefer the order: reception $\rightarrow$ perception $\rightarrow$ apperception, while others favour perception $\rightarrow$ apperception $\rightarrow$ reception.
} 
which were the focal point of this research, narrative concerts well known as musical fairy tales, concerts for families with children and operas for children (Burgrova, 2007). According to Drabek a feature of educational concerts is the presence of didactic interaction facilitating aesthetic interactions. Didactic interaction occurs between the teacher or in some cases a moderator or the artist of the musical composition and the pupils, it facilitates the active contact of the pupils with the artwork therefore aesthetic interaction. The concert model well known in previous decades has been in practise gradually replaced by a motivational model, "which is essentially based on a musical experience behind which educational possibilities are hidden and the teacher must prepare and develop them himself." (Hrabinova, 2007: 43) Concerts for children have also undergone a fundamental change in dramaturgical concept "from a classical concert with commentary from a moderator to a scenic musical format with a strong emotional impact, supported by the active involvement of children in the audience and groups of children performing directly on the stage." (Cunderlikova, 2007: 40). Within this context the creative, multi aesthetic projects of Belo Felix and Juraj Hatrík, who is established in art pedagogy, are bearers of a powerful ethical message and admirable invention.

The inclusion of concerts for children to educational activities is just one part of issue of developing their musicality. Each of them provides the child recipient with new impressions enhanced by the authenticity of the message as well as the atmosphere of the surroundings. Along with the aesthetic experiences they also deepen their musical and general education, increase how cultured they are and the level of their social behaviour. For a significant proportion of children it is the first and sometimes the only time they will ever attend a concert of classical music.

\section{Pedagogical research}

While carrying out this research it was our endeavour to find out, what is the attitude of pupils to art music at the lower level of secondary school education, if it is possible to change these attitudes and what role in the process of changing these attitudes plays the perception of music through concerts of classical music. The research problem was developed by establishing research questions: Does the perception of art music play a role in influencing the interests of pupils on the lower secondary level of school education? Can attending concerts as a part of musical education positively influence the relationship that pupils have to classical music? Can the active perception of art music change the receptivity of pupils to attending concerts of classical music?

The fundamental hypothesis Active perception of art music influences pupils at the lower secondary level of education to form a positive relationship to classical music and from them can raise potential concert goers was broken down into four sub hypotheses. A sample group was chosen from pupils attending the second tier of primary school in the Slovak Republic. The experimental group (Ex) were pupils from class 7A and the control group (Co) were pupils from $7 \mathrm{~B}$ at the chosen primary 
school. An independent variable of the research was the age of the pupils and the dependent variable was the pupil's relationship to the perception of art music. The research was conducted in three stages - pre experimental measuring, experimental procedure and post experimental measuring. The evaluation of the results was carried out using a quantitative-qualitative method. An emphasis was placed on the analysis of causal relationships between the variables. The qualitative component of the research was focused mainly on the interpretation and understanding of the importance of the recorded changes.

The experimental procedure was an educational model that was created for this specific research. It consisted of a series of four concerts entitled the melody of my heart. The aim of the educational model was to create for the pupils in the experimental group a program during which they would gain new perceptual experiences that would lead to changes in their values pertaining to the perception of art music. The educational aims where from the cognitive, affective and psychomotor domains.

Cognitive aims: The pupil knows the basic musical means of expression of art music of different musical periods. He knows the characteristic features of each period of musical development. He knows information and interesting details from the field of production and reproduction of music relating to the interpretation of musical compositions and their authors.

Affective aims: The pupil is able to accept art music as a part of society's cultural inheritance.

Psychomotor aims: The pupil is able to identify himself as a percipient of art music and is able to cooperate on the perception of this music and take an active approach to perceptual activities.

In the second stage of the research pupils from the experimental group attended the musical perception activities of the experimental procedure. It was made up of the aforementioned concerts entitled the melody of my heart. The first three concerts took place in the concert classroom of a primary art school, the closing concert which was the climax of the project took place in the artistically inspiring surroundings of the exhibition hall of the Gallery of Miloš Alexander Bazovský in Trenčin. The evaluation of the results from the survey done in the first and third stage of the research allowed for the verification of the sub hypotheses of the research.

\section{H1: Art music as a class of music as defined by a set of certain parameters} is not preferred to other musical genres.

Hypothesis H1 was confirmed by the research. The results of the evaluation of the responses confirmed that the pupils when they choose the object of their personal perception listen to mainly non art music; the level was as high as $85 \%$ of pupils in the experimental and control groups. It was confirmed that art music as a class of music as defined by a set of certain parameters is not preferred to other musical genres. The following graph offers interesting information about the method pupils on the lower level of secondary school education come into contact with classical music. 


\section{Graph No. 1}

Compositions known as classical music pupils know ...

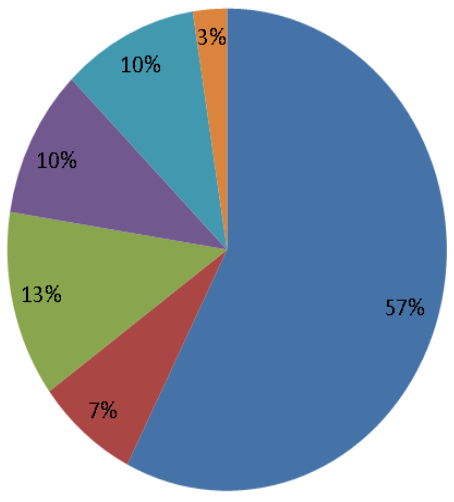

From school

From the radio or television channels

From the internet

- From concerts

ather

I don't know any

From the responses it is obvious that school plays an incredibly important role in familiarising pupils with art music and therefore in forming the relationship that pupils have to it.

H2: The perception of art music affects the pupil's relationship to compositions of classical music.

Hypothesis $\mathrm{H} 2$ is confirmed. It was confirmed by comparing the responses given by pupils in the experimental and control group to a question made up of four statements that the pupils responded to in the first and third stage of the research. Almost half of the experimental group before the experimental procedure agreed with the statement 'Classical music is not for my age group' but in the second measurement this dropped to $22.2 \%$. About a quarter of the pupils didn't agree with the statement before the series of concerts and their attitudes changed during the experimental procedure so that after $50 \%$ of the pupils from the experimental group didn't agree. In the control group the percentage of responses no and more no than yes was identical in the first and second measurements so no change in attitude was registered. 
Graph No. 2

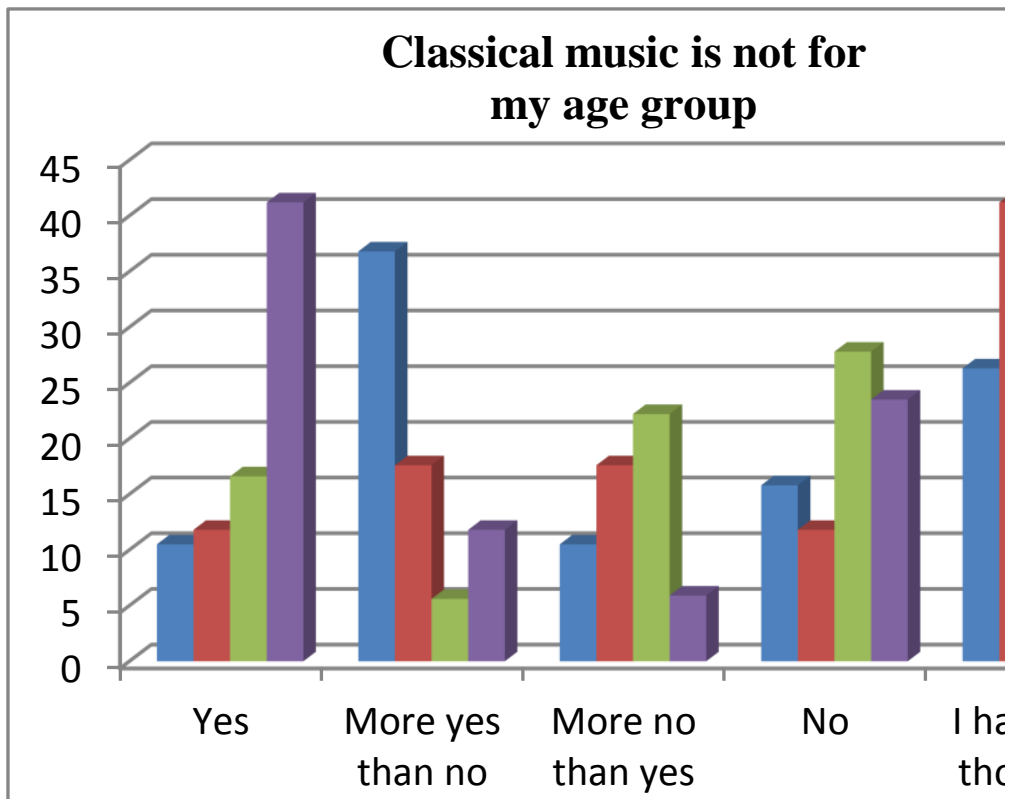

A significant difference was recorded in the response yes and more yes than no of the students in the experimental and control groups to the statement Classical music is incomprehensible. Before the experimental procedure almost half of the experimental group agreed or more agreed with the statement whereas after the experimental procedure only one pupil agreed. This difference represents $42 \%$. This change in attitude relates to the change in number of pupils who chose the response no - I don't agree, where there is recorded a difference of $45.2 \%$. The difference between the responses given by the control group is significantly lower.

\section{Graph No. 3}

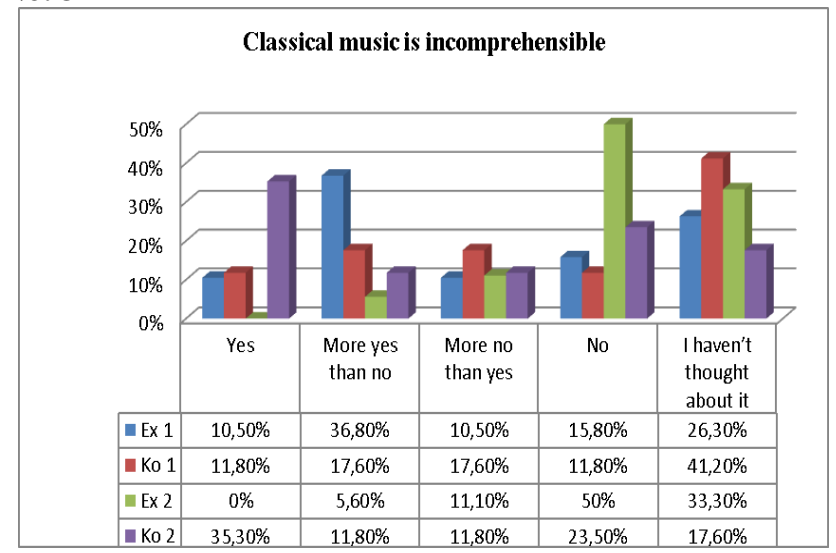


The analysis of the degree of agreement with the statement Classical music is soothing illustrates that the responses yes and more yes than no from the experimental group increased by almost $15 \%$, whereas in comparison in the control group there was a decrease of $0.1 \%$. A significantly altered result is a growth of almost $19 \%$ in the response yes to this statement and in the second measurement of the experimental group the response yes was given $55 \%$ of the time. Only one pupil hadn't thought about this issue from the experimental group.

\section{Graph No. 4}

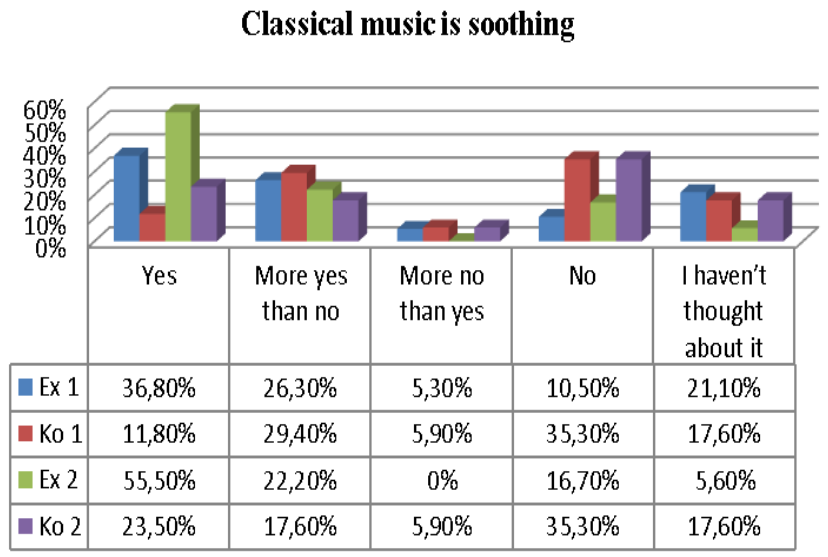

In connection to the statement I like classical music there is a significant difference of almost $29 \%$ in the number of responses more yes than no from the experimental group. It is interesting to note that no pupils from the experimental group selected the response I haven't thought about it.

Graph No. 5

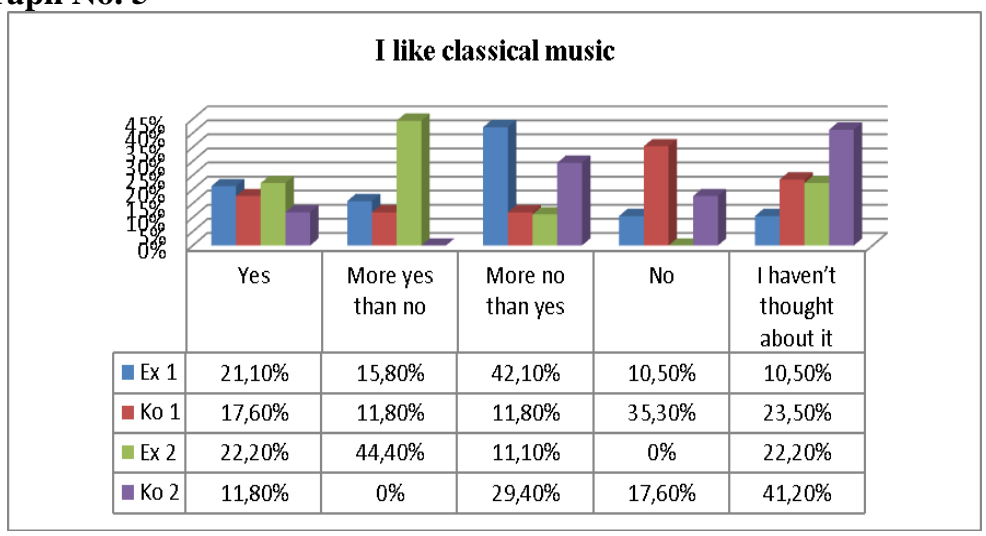


H3: Identification of compositions of art music isn't decisive in determining the pupil's relationship to this type of music.

The task Write the names of compositions of classical music that you know was included in the questionnaire in both the first and third stage of the research. A significant difference was observed in the answers of the pupils from the experimental group; this was that in the second measurement the growth in the number of answers given was $200 \%$. The list of known compositions included compositions that were presented as part of the concerts in the experimental procedure. The total number of answers from students in the control group was almost identical in both cases.

\section{Graph No. 6}

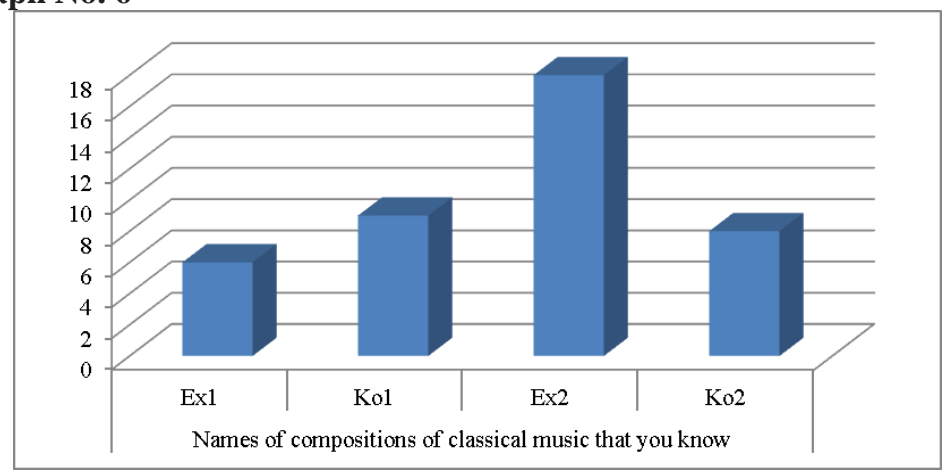

Hypothesis H3 was not confirmed. Even though in the returned questionnaires was recorded a relatively low number of identified compositions and there were certainly some gaps in their knowledge the pupils in the experimental group identified three times the number of compositions of art music in the second round of measurement as opposed to the first. The growth was mainly made up of compositions that had been heard during the concerts. This fact means the argument that the identification of compositions of art music isn't decisive in determining the pupil's relationship to this type of music must be rejected. It also confirms that knowing certain studied elements, in this case names of compositions, can't be considered unimportant but is an outward expression of the internal change of the pupil's attitude to compositions of classical music.

H4: Active perception influences the pupil's openness to potentially attending concerts.

Hypothesis $\mathrm{H} 4$ was confirmed. The research demonstrated a marked change in the pupil's openness to potentially attending concerts. A concert in a concert hall would be chosen by $15.8 \%$ more pupils from the experimental group after the experiment in comparison to before. Before the experimental procedure almost half of the students in the experimental group wouldn't have chosen any concert to attend whereas in the second 
measurement this amount had fallen to $21.1 \%$. The replies of pupils in the control group were similar in both measurements.

\section{Graph No.7}

\begin{tabular}{|c|c|c|c|c|}
\hline \multicolumn{5}{|c|}{$\begin{array}{l}\text { If you had in the future the chance to attend a concert of } \\
\text { classical music, would you choose? }\end{array}$} \\
\hline \multicolumn{5}{|l|}{$80 \%$} \\
\hline \multicolumn{5}{|l|}{$70 \%$} \\
\hline \multicolumn{5}{|l|}{$50 \%$} \\
\hline \multirow{2}{*}{\multicolumn{5}{|c|}{$\begin{array}{l}40 \% \\
30 \%\end{array}$}} \\
\hline & & & & \\
\hline \multirow{2}{*}{\multicolumn{5}{|c|}{$\begin{array}{l}20 \% \\
10 \%\end{array}$}} \\
\hline & & & & \\
\hline $0 \%$ & $\begin{array}{l}\text { Concert in a } \\
\text { concert hall }\end{array}$ & $\begin{array}{l}\text { Concert in a } \\
\text { public square }\end{array}$ & $\begin{array}{l}\text { Concert in } \\
\text { school }\end{array}$ & $\begin{array}{c}\text { I wouldn't } \\
\text { choose a concert } \\
\text { of classical } \\
\text { music }\end{array}$ \\
\hline$=\operatorname{Ex} 1$ & $42,10 \%$ & $0 \%$ & $10,50 \%$ & $47,40 \%$ \\
\hline Ko 1 & $29,40 \%$ & $0 \%$ & $11,80 \%$ & $58,80 \%$ \\
\hline$=\operatorname{Ex} 2$ & $57,90 \%$ & $10,50 \%$ & $10,50 \%$ & $21,10 \%$ \\
\hline Ko 2 & $29,40 \%$ & $0 \%$ & $0 \%$ & $70,60 \%$ \\
\hline
\end{tabular}

\section{Research conclusions}

Three of the four sub hypotheses were confirmed and one of the sub hypotheses was not confirmed. The results that were obtained to the fullest extent confirmed the basic hypothesis that Active perception of art music influences pupils to form a positive relationship to classical music and from them can raise potential concert goers. Not only so that that concert halls would be full of listeners but for the development of the pupil's personality.

Even though art music does not currently belong to the type of music that pupils on the lower level of secondary school education would normally prefer perception of this type of music can positively contribute to changing the pupil's attitude, our research is also proof of this. Active perception of classical music causes a positive change to pupil's opinions about the fact that; it is a style of music for young people too, it is possible to understand this type of music, its seemingly incomprehensibility is not a permanent characteristic, it is possible to understand its message, perception of this type of music acts as a soothing factor in the fast paced everyday life and the quickly changing lifestyles of consumers of music, there are many compositions that pupils and teenagers can enjoy.

Active perception of art music brings with the change of attitude also the development of their ability to identify specific compositions so it impacts the cognitive area of their orientation in the world of classical music. The research also confirmed that active perception of this music positively influences the pupil's openness to potentially attending concerts. The results of this research unequivocally confirmed that the role of the school in the formation of a pupil's attitude to music is irreplaceable. 


\section{Conclusion}

Music teachers at different levels and types of schools are convinced of the need for active perception of music. For it to be possible to give space to the perception of art music for its formative influence on the pupil's personality it is necessary for concerts of art music to be included in the educational activities of primary schools. Educational aims which such a musical educational project should fulfil should be based on the educational program of each school which determines the aims, extent, content and performance standards and the abilities of the graduates of each subject. For teachers and pupils preparing and realising such concerts is an activity which many times they carry out as something above and beyond their normal work or study commitments. The result though is an artistic experience which neither the listener nor the performer cannot perceive in any other form. In the work of music teachers is often heard the sentence whose meaning is clearly captured by the quote from Balcarova "To make the perception of art music a lifelong need of the child means to face the one-sidedness of their artistic orientation." (Kalafutova-Balcarova: 2001). We would add that not just artistic. Music can change the life orientation of a person.

\section{Bibliography}

BURGROVA, K. 2007. Koncerty pre deti a mladez - vysledky prieskumu v zakladnych skolach na Slovensku (Bratislava, Presov). Koncerty pre deti a mladez. Presov : Presovska univerzita v Presove, Pedagogicka fakulta. pp. 110-126. ISBN 978-80-8068-647-5.

CUNDERLIKOVA, E. 2007. Vychovne koncerty pre skoly Hudobneho centra Bratislava. Koncerty pre deti a mladez. Presov: Presovska univerzita v Presove, Pedagogicka fakulta. ISBN 978-80-8068-647-5, pp. 40-42.

DRABEK, V. 1987. ABC vychovnych koncertu. Prague: Divadelni ustav, Praha.

FELIX, B. 2013. Aktivna percepcia v priprave ucitelov. Kontexty hudobnej pedagogiky I. Banska Bystrica: Univerzita Mateja Bela, Pedagogicka fakulta. pp. 32-62. ISBN 9788055705538.

FLOTZINGER, R. 2002-2015. (Hg.) Ostereichisches Musiklexikon. Gesamtwerk. Band 1. Wien 2002-2015. ISBN 139783700130437.

HERDEN, J. 2010. Aktivni poslech. Hudba pre deti - multimedialne projekty. Banska Bystrica : Univerzita Mateja Bela, Pedagogicka fakulta, pp. 35-41. ISBN 9788055700755.

HRABINOVA, M. 2007. Kriteria Hudobneho centra Bratislava pre vychovne koncerty. Koncerty pre deti a mladez. Presov: Presovska univerzita v Presove, Pedagogicka fakulta. ISBN 978-80-8068-647-5, pp. 43- 44.

KALAFUTOVA-BALCAROVA, B. 2001. Recepcia hudby. Presov: Suzvuk. ISBN 80-968566-4-2.

KOŁODZIEJSKI, M. 2007. Development of the musical audiation at the beginning of the first educational stage. Person, Color, Nature, Music: scientific articles of V International Conference, October 17-21. Daugavpils. 
University Akademiskais Apgads "Saule". ISBN 978-9984-14-367-5. pp. 292-301.

KOŁODZIEJSKI, M. 2010. Kreatywnosc nauczyciela muzyki autoprezentacja [w:] Pedagogika kreatywna wyzwaniem edukacji XXI wieku. Opole: Wydawnictwo Naukowe Uniwersytetu Opolskiego. ISBN 978-83-7395-400-7.

KOLOSTOVA, M. 2014. Music workshop in university education of teachers at the Faculty of Education, Matej Bel University in Banska Bystrica. Kreatyvność w edukaciji muzicznej. Praca zbiorowa pod redakcją naukovą Macieja Kołodziejskego. Pułtusk: Akademia Humanistyczna im. Aleksandra Gieysztora. ISBN 978-83-7549-190-6. pp. 77-90.

MASTNAK, W. 1994. Zmysly - umenie - zivot. Presov: Matus music. ISBN 80-967089-1-0

PAPOVA, J. 2015. Aktivna percepcia artificialnej hudby na nizsom sekundarnom stupni vzdelavania. Banska Bystrica : Univerzita Mateja Bela, Pedagogicka fakulta. Available online: www.public.sk/web/kniznica/elpub/ dokument/Kopcakova1/subor/2_cast.pdf

PaedDr. Marianna Kološtová, Ph.D.

Matej Bel University

Department of Music education

Faculty of Education

Ružová 13, 97411 Banská Bystrica

Slovakia

mariana.kolostova@umb.sk

Mgr. Jarmila Papová

Základná umelecká škola

Nám. SNP 388/2

91101 Trenčín

Slovakia 